\title{
AGRI-FOOD SECTOR POTENTIAL IN THE CHOSEN CIS COUNTRIES
}

\begin{abstract}
Since the early 1990s, the chosen CIS ${ }^{l}$ countries (Armenia, Azerbaijan, Belarus, Georgia, Kazakhstan, Moldova, Russia and Ukraine) have undergone transition from a centrally planned to a market-oriented economy. Several countries from the group have sizeable agricultural sectors. Countries like Russia and Ukraine play an important role on the international markets. The untapped agricultural potential of these countries is the subject of this paper. The main goal of this paper is to improve the understanding of the agri-food sector performance in the chosen CIS countries. The paper provides content analysis of country reports, cross-country SWOT analysis of agri-food sector performance and development potential supplemented with expert evaluation.
\end{abstract}

Keywords: agriculture, food sector development, CIS countries, transition.

JEL codes: F63, L66, O13, O47, O57.

\section{Introduction}

In a world where long-term food security is an issue, it is important to evaluate the untapped potential for food, feed and biomass production. Several countries of the Commonwealth of Independent States (CIS) have sizeable agricultural sectors. Yet, although countries like Russia and Ukraine play an

\footnotetext{
${ }^{1}$ Commonwealth of Independent States (CIS) was created in December 1991. At present, the CIS unites: Azerbaijan, Armenia, Belarus, Kazakhstan, Kyrgyzstan, Moldova, Russia, Tajikistan, Turkmenistan and Uzbekistan. Georgia is a former member state and Ukraine is an associate member state. Subject to this study are: Azerbaijan, Armenia, Belarus, Georgia, Kazakhstan, Moldova, Russia and Ukraine.
} 
important role on the international cereal markets as exporters, productivity in these countries is far below what would be possible according to agro-ecological attainable yields (Bruinsma, 2009; FAO, 2012). At the same time, there is a large supply of underutilised or abandoned agricultural land in the CIS (Foresight, 2011). If these countries had fully used their agricultural potential it might have had important consequences for their position on the international markets as well as for the bilateral trade relations of the EU with these neighbouring countries.

Since the early 1990s, the chosen CIS countries (Armenia, Azerbaijan, Belarus, Georgia, Kazakhstan, Moldova, Russia and Ukraine) have undergone transition from a centrally planned to a market-oriented economy. In the context of agricultural production and trade, the economic and institutional reform meant the abolishment of central controls and planning, privatisation of production assets and land reform, reductions in government intervention in internal markets, trade liberalization and economic stabilization (Erjavec, Volk, Rac, Kožar, Pintar and Rednak, 2017; Buchenrieder, Hanf and Pieniadz, 2009; Lerman, 2009; Csaki and Forgacs, 2008; Lerman, Csaki and Feder, 2004). For the above-mentioned countries, agriculture still represents an important percentage of both the GDP and employment (Swinnen, van Herck and Vranken, 2010; Lerman, 2004) and social safety net (Erjavec, Volk, Rac, Kožar, Pintar and Rednak, 2017).

The analysed countries have common legacy and started transition to the market economy from a similar starting point. This fact allows us to state that for the selected former Soviet Union countries it is possible to distinguish typical environmental elements. However, the current development of agricultural and food sectors differs significantly. This means that unique elements, defining specific characters of the environment, are introduced in each country (Rylko, Khotko, Abuzarova, Yunosheva and Glazunova 2015; Urutyan, Yeritsyan and Mnatsakanyan, 2015; Syzdykov, Aitmambet and Dautov, 2015; Moroz, Stratan, Ignat and Lucasenco, 2015; Nivievskyi, Stepaniuk, Movchan, Ryzhenkov and Ogarenko 2015; Khalilov, Shalbuzov and Huseyn, 2015; Bluashvili, Sukhanskaya, 2015; Akhramovich, Chubrik and Shymanovich, 2015). The origin of peculiarities of agricultural and food sectors is determined by diversity of selected reforms and national agricultural and food policies (Erjavec, Volk, Rac, Kožar, Pintar and Rednak, 2017), directions of foreign policy, geographical situations, geologic and climate conditions, etc. Nevertheless, the possible contribution of these factors to fully tap the agricultural potentials of CIS countries was not actually researched systematically (Lerman, Csaki and Feder, 2004; Swinnen and Rozelle, 2006; von Cramon-Taubadel and Nivyevskiy, 2012; Liefert and Liefert, 2012; Arakelyan, 2013).

The main goal of this paper is to improve the understanding of the agri-food sector performance in the chosen CIS countries. Therefore, several tasks have been undertaken: 
1. To investigate the main strengths and weaknesses of the agri-food sector on the basis of the content analysis of the country studies.

2. To emphasize the main opportunities and threats of the agri-food sector development in the above-mentioned countries.

3. To figure out the main and specific problems in agri-food sector development in the analysed countries.

4. To analyse expected potential growth directions in agricultural and food sector based on expert evaluation.

\section{Research methods}

This paper presents the results of the study performed under the EU $7^{\text {th }}$ Framework Programme AGRICISTRADE ${ }^{2}$ project. The study combines methods of qualitative and quantitative analysis to give a more comprehensive understanding of the agricultural and food sectors' situation in the eight analysed countries. The quantitative analysis justifies the comparison of the state of affairs between the countries. The impact of the recent events in Ukraine, which had affected development of the main indicators, was eliminated from the study. In order to cover data gaps and get useful insights on agricultural and food sector development directions and potentials, the qualitative analysis was conducted by chosen experts from every country. Experts represented the leading country institutions specialised in economic research on agriculture.

The questions for the expert evaluation were prepared according to the content analysis of available research studies and country reports (Rylko, Khotko, Abuzarova, Yunosheva and Glazunova, 2015; Urutyan, Yeritsyan and Mnatsakanyan, 2015; Syzdykov, Aitmambet and Dautov, 2015; Moroz, Stratan, Ignat and Lucasenco, 2015; Nivievskyi, Stepaniuk, Movchan, Ryzhenkov and Ogarenko, 2015; Khalilov, Shalbuzov and Huseyn, 2015; Bluashvili and Sukhanskaya, 2015; Akhramovich, Chubrik and Shymanovich, 2015), which were presented under the project by expert groups in all analysed countries.

These led us to highlight the main strengths, weaknesses, opportunities and threats (SWOT) of the agricultural and food sectors in the analysed countries. Then, the experts were asked to indicate the relevance of the particular factors for the country. The relevance of these factors was marked on three levels "low", "intermediate" and "high". In addition, all experts were asked to emphasize the main problems faced by agricultural and food sector. Cross-country analyses provide us with similarities and differences between the main problems and bottlenecks in all of the analysed countries. Valuation method applied by the employed experts' gave an insight into the potential of sectors' developments and specified issues which were proposed by experts to improve the situation.

\footnotetext{
${ }^{2}$ AGRICISTRADE - Exploring the potential for agricultural and biomass trade in the Commonwealth of Independent States (more info on www.agricistrade.eu).
} 


\section{SWOT analysis of the agricultural and food sector in the CIS}

The main strength of agricultural and food sectors of all the analysed countries, except Belarus, is good agroclimatic conditions (Table 1). Russia covers a large area and occupies regions with different agroclimatic conditions. However, according to the current direction of its national policy the country has sufficiently good conditions, to allow for ensuring national food self-sufficiency and improving export of niche products.

Table 1

Strengths of the agricultural and food sector development

\begin{tabular}{|c|c|c|c|c|c|c|c|c|}
\hline & \multicolumn{3}{|c|}{ Transcaucasia } & \multirow{2}{*}{$\begin{array}{c}\text { Central } \\
\text { Asia }\end{array}$} & \multicolumn{4}{|c|}{ European countries } \\
\hline & $\mathrm{AM}$ & $\mathrm{AZ}$ & GE & & MD & BY & UA & RU \\
\hline $\begin{array}{l}\text { Favourable agroclimatic } \\
\text { conditions for the niche } \\
\text { products }\end{array}$ & +++ & +++ & +++ & +++ & +++ & + & +++ & +++ \\
\hline Relatively low input costs & +++ & +++ & +++ & +++ & +++ & +++ & ++ & +++ \\
\hline $\begin{array}{l}\text { Potential of arable land area } \\
\text { enlargement }\end{array}$ & +++ & +++ & ++ & +++ & + & + & + & +++ \\
\hline
\end{tabular}

AM - Armenia; AZ - Azerbaijan; GE - Georgia; KZ - Kazakhstan; MD - Moldova; BY - Belarus; UA - Ukraine; RU - Russian Federation.

Relevance of the factor for the country: "+" - low; "++"- intermediate; "+++"- high.

Source: based on the synthesis of country reports (AGRICISTRADE, 2015) and expert valuation.

One of the main strengths of the aforementioned countries are relatively low input costs securing higher competitiveness. It should be noted that the origin of this situation differs from country to country and has natural or artificial nature. As a rule, labour costs in the agricultural and food sector of the analysed countries are lower than in countries with well-functioning market economy. The comparison of labour costs between countries shows significant fluctuations of salaries too. The attractiveness of other inputs could be determined by state support or special conditions in the domestic market. Some countries benefit from lower fuel and energy prices if they are net exporters of primary energy products (e.g., Russia and Azerbaijan), import them at a price lower than the worlds' average (e.g., Belarus) or introduce a state intervention (for example, fuel subsidies). Countries often benefit from developed domestic agriculture-related industries (for example, Russia and Belarus have local industry of fertilizers, machinery, etc.).

The strong decrease in agricultural production and the initial stage of the new trade networks' formation after the USSR collapse, reserved a good potential for the agricultural and food sector development. All countries, except Belarus, Moldova and Ukraine, have more or less significant potential to increase the area of land for agricultural purposes. The development potential of Belarus is limited 
by the relatively low land productivity, unfavourable climate conditions and the exclusion of certain areas from agricultural use after the Chernobyl accident in 1986. Moldova and Ukraine have a high share of agricultural land in the structure of land and face a challenge of preserving the productive potential of soil.

Unfortunately, the analysed countries also inherited common weaknesses, which were deep-seated adapting values of the central planning system. They resulted in slowing down the agricultural and food sectors' development during the transition period (Table 2).

Table 2

Weaknesses of the agricultural and food sector development

\begin{tabular}{|c|c|c|c|c|c|c|c|c|}
\hline & \multicolumn{3}{|c|}{ Transcaucasia } & \multirow{2}{*}{$\begin{array}{c}\text { Central } \\
\text { Asia } \\
\text { KZ }\end{array}$} & \multicolumn{4}{|c|}{ European countries } \\
\hline & $\mathrm{AM}$ & $\mathrm{AZ}$ & GE & & MD & BY & UA & RU \\
\hline Low productivity and yields & +++ & ++ & +++ & +++ & +++ & ++ & ++ & ++ \\
\hline Old equipment, machinery & +++ & ++ & & +++ & +++ & & & +++ \\
\hline $\begin{array}{l}\text { Archaic or absent irrigation, } \\
\text { drainage system }\end{array}$ & +++ & ++ & +++ & +++ & +++ & & & \\
\hline $\begin{array}{l}\text { Underdeveloped transport } \\
\text { system and logistic } \\
\text { infrastructure }\end{array}$ & +++ & ++ & +++ & +++ & ++ & & + & + \\
\hline $\begin{array}{l}\text { Underdeveloped insurance } \\
\text { and loan systems }\end{array}$ & +++ & ++ & +++ & +++ & ++ & & +++ & \\
\hline $\begin{array}{l}\text { Underdeveloped market } \\
\text { access system }\end{array}$ & & ++ & +++ & & +++ & & ++ & \\
\hline $\begin{array}{l}\text { Impact of bureaucracy, } \\
\text { excessive state regulations } \\
\text { and corruption }\end{array}$ & +++ & ++ & + & +++ & +++ & +++ & +++ & \\
\hline $\begin{array}{l}\text { Need for certification, } \\
\text { agri-food standards } \\
\text { or quality requirements, } \\
\text { control development issues }\end{array}$ & +++ & ++ & & +++ & +++ & +++ & +++ & +++ \\
\hline Need for land consolidation & +++ & +++ & +++ & & +++ & & +++ & \\
\hline $\begin{array}{l}\text { Need for small-scale } \\
\text { farming consolidation }\end{array}$ & +++ & & & +++ & ++ & & +++ & \\
\hline $\begin{array}{l}\text { Stakeholders cooperation } \\
\text { improvement }\end{array}$ & +++ & +++ & +++ & +++ & ++ & & +++ & \\
\hline Shortage of investors & & +++ & & +++ & +++ & & +++ & \\
\hline $\begin{array}{l}\text { Need for rural infrastructure } \\
\text { development }\end{array}$ & +++ & & +++ & +++ & +++ & +++ & +++ & \\
\hline $\begin{array}{l}\text { Isolated research } \\
\text { and education system }\end{array}$ & +++ & ++ & +++ & +++ & +++ & +++ & +++ & +++ \\
\hline Shortage of qualified labour & +++ & ++ & +++ & +++ & +++ & +++ & +++ & +++ \\
\hline
\end{tabular}

Designations and notes as in Table 1.

Source: based on the synthesis of Country reports (AGRICISTRADE, 2015) and expert valuation. 
Most of the typical weaknesses could be overcome by implementing a sustainable policy of the agricultural and food sector development. However, the situation is complicated due to budget constraints and lack of appropriate funding from other sources, which makes a significant progress, shifting from the factual to the potential state of the agricultural and food sector, unlikely. Low productivity, lack of qualified labour and drawbacks of the national agricultural education and research organizations are the most acute problems, which must be solved. Majority of the countries stress the importance of machinery and equipment renewal as well as infrastructural and institutional development issues.

The most important and commonly repeated opportunities and threats of the national agricultural and food sectors in the eight countries are summarized in Table 3. The main opportunities of sectors' potential development are untapped domestic markets and demand for niche products on the world's market. Positive changes in investment environment and level of yields (productivity) are anticipated to reduce the gap between the actual and potential possibilities of the agricultural and food sector.

Table 3

Opportunities and threats of the agricultural and food sector development

\begin{tabular}{|c|c|c|c|c|c|c|c|c|c|}
\hline & & \multicolumn{3}{|c|}{ Transcaucasia } & \multirow{2}{*}{$\begin{array}{c}\begin{array}{c}\text { Central } \\
\text { Asia }\end{array} \\
\mathrm{KZ}\end{array}$} & \multicolumn{4}{|c|}{ European countries } \\
\hline & & AM & $\mathrm{AZ}$ & GE & & MD & BY & UA & RU \\
\hline \multirow{4}{*}{ 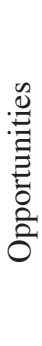 } & $\begin{array}{l}\text { Untapped domestic market } \\
\text { potential }\end{array}$ & +++ & +++ & & +++ & ++ & + & + & +++ \\
\hline & $\begin{array}{l}\text { Good potential for } \\
\text { export increase }\end{array}$ & +++ & +++ & +++ & +++ & ++ & +++ & +++ & +++ \\
\hline & $\begin{array}{l}\text { Improvement of } \\
\text { investment environment }\end{array}$ & +++ & +++ & +++ & +++ & +++ & & +++ & \\
\hline & $\begin{array}{l}\text { Yields growth, productivity } \\
\text { increase }\end{array}$ & & +++ & & +++ & +++ & + & +++ & +++ \\
\hline \multirow{3}{*}{ 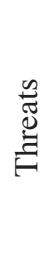 } & $\begin{array}{l}\text { Deeper penetration of foreign } \\
\text { producers on domestic market }\end{array}$ & +++ & +++ & & +++ & ++ & +++ & ++ & + \\
\hline & $\begin{array}{l}\text { Urbanization and emigration } \\
\text { of the rural population }\end{array}$ & & +++ & & +++ & +++ & +++ & +++ & \\
\hline & $\begin{array}{l}\text { Soil erosion, violation } \\
\text { of nutrients' balance }\end{array}$ & & +++ & & +++ & +++ & & +++ & \\
\hline
\end{tabular}

Designations and notes as in Table 1.

Source: based on the synthesis of country reports (AGRICISTRADE, 2015) and expert valuations.

It should be noted that market liberalization is understood as a threat to the national agricultural and food sector. The deeper penetration of foreign producers on domestic markets is named as a challenge. Experts also stressed the im- 
portance of social and environmental issues for the future development of national sectors. The most visible social challenge is the aging of the population in rural areas due to the high level of migration. This issue causes a shortage of labour force and changes in the national structure of agriculture. Some countries are also faced with soil degradation issues, which could significantly reduce the potential of the national agricultural and food sector.

\section{Main and specific problems in agricultural and food sector of the CIS}

All the country experts were asked to point out the main problems relevant to a given country. As a result, we see that the problems are connected to each other in different countries. Major concerns are related to two main problems. The first one is connected with obsolete infrastructure in rural areas, outdated irrigation and drainage systems. The second one is related to human capital underdevelopment, low technical skills, education, scientific developments. These two problems were mentioned in seven out of eight country reports.

Analyses led to investigation also of specific problems in all of the analysed countries. Armenia, Azerbaijan, Georgia and Kazakhstan are concerned about small-scale farming and land issues. In particular, these countries stressed the stocked land consolidation processes and weak position of small farms on the market. Belarus, Kazakhstan, Russia and Ukraine pointed out the ineffectiveness of subsidy mechanisms for agricultural sector. Low productivity and yield problem is relevant for all the analysed countries, but was underlined as one of the most important problems in Armenia, Azerbaijan and Ukraine.

The problem of obsolete technological base in agricultural production/processing was underlined in small countries like Armenia and Azerbaijan as well as in a large country like Russia. Growing natural risks and environmental challenges were highlighted by Belarus, Kazakhstan, Moldova and Russia. Armenia and Belarus are a huge concentration of foreign trade in agri-food and forest products on Russian market (around $80 \%$ of total agri-food and forest products exports is oriented towards the Russian market). It was stressed by experts also as one of the most important problems in these countries. It needs to be kept in mind that such high export concentration is very risky and makes strong dependency on political events and macroeconomic developments in Russia.

Small countries, like Moldova and Armenia, were concerned about low competitiveness of the agri-food sector and difficulty to enter new markets with low amounts of production, specific technical requirements on foreign markets, etc.

\section{Agri-food sector potential in the analysed countries}

AGRICISTRADE experts were asked to identify the most important areas of the national agricultural and food sector with the highest potential of development in the immediate future. The comparison of the most prospective areas of agriculture in the eight countries is provided in Table 4. 
Table 4

Expected potential growth directions in agricultural and food sector

\begin{tabular}{|c|c|c|c|c|c|}
\hline & & Crop production & Vegetables & Fruit, berries, nuts & Livestock, fishery \\
\hline \multirow{3}{*}{ 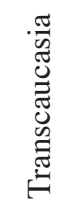 } & $\mathrm{AM}$ & - & + & + & + \\
\hline & $\mathrm{AZ}$ & + & + & + & + \\
\hline & GE & - & - & + & - \\
\hline 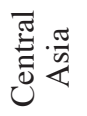 & $\mathrm{KZ}$ & + & - & - & + \\
\hline \multirow{4}{*}{ 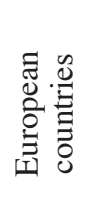 } & MD & + & - & + & - \\
\hline & BY & + & + & + & + \\
\hline & UA & + & + & + & + \\
\hline & RU & + & + & + & + \\
\hline
\end{tabular}

Designations as in Table 1 .

Relevance of the area for the country: "+"-attractive for potential development; "-"- unattractive for potential development or not mentioned.

Source: based on the synthesis of country reports (AGRICISTRADE, 2015) and expert valuations.

Ukraine has very good agroclimatic conditions but the performance of its agricultural sector is relatively poor (though it is high enough compared to the analysed countries). The lag is preconditioned by the domination of low capital intensity farms. These farms cannot afford investing in modern machinery, high-quality seeds, plant protection products and fertilizers. Fertile soils partly compensate these drawbacks and make Ukraine competitive in case of large number of agri-food products (cereals, flour, oilseeds, vegetable and animal fats, vegetables, fruit, residues of food industry, animal fodder, dairy products, etc.). Cheap feed and raw materials supply for the livestock sector and the processing industry are also important driving forces of the agri-food market development. Some research on the identification of organic production potential was conducted and significant efforts to develop the institutional framework of this niche were made. Untapped potential of the organic market could be an attractive perspective for the development of the country, as Ukraine has fertile soils which could give a competitive advantage. The huge debt incurred in relation to natural gas and interruptions in energy supply could encourage investing in the development of biomass production in the immediate future.

The driving force of the agricultural and food sector development potential in Russia is a state policy of import substitution. Such a policy is inefficient and costly from the economic point of view, but it should certainly increase produc- 
tion of particular agri-food products (i.e. fruits, vegetables, meat and dairy products). Some positive impact on agriculture-related industries is also possible. Though the coverage of the domestic market gaps in pork, vegetable and fruit production could be quick, production development in agricultural inputs, beef and dairy will take time. A significant growth in the agricultural and food sector is expected. Agricultural land restructuring and increase in productivity, which is below the average of countries with similar agroclimatic conditions, will reduce the gap between the actual and possibilities potential of the sector. Russia will probably strengthen production and export of grain and oilseed, which have a natural competitive advantage. Although the organic product market is an attractive niche, the institutional environment is not favourable for the rapid development of this area. Biomass potential will not be developed as it excludes valuable arable lands from production and endangers national self-sufficiency and raises food security issues.

The situation of Belarus is distinctive among the other countries. Belarus has no potential to increase arable area as land is almost fully utilised. The performance of the agricultural sector is close to that recorded in neighbouring countries of the EU with the exception of some products (e.g. rapeseed, wheat, maize, barley, etc.). The moderate potential of development is seen in yields increase and regulation of the structure of the cultivated crops. A reasonable growth of vegetables (cabbage, carrot, onion, cucumber), apples and strawberries is possible due to demand in domestic and Russian markets. The development potential of the livestock sector is an attractive direction. The most promising areas are dairy products and related beef production, pork and poultry production. The growing demand for organic products on the domestic market shows that this production also could be an attractive niche in the immediate future. Privileged prices for energy do not encourage investing in the further development of biomass production.

Moldova has good climate conditions and fertile soils, however, yields are below the EU average. Old equipment and machinery, labour force qualification issues and traditional production technologies predetermine low yields and productivity. The most attractive commodities with export potential are sunflower, walnuts, wheat and maize. Moldova has potential in wine and fruit production which could be realized on new markets. Land degradation issues are very important due to overintensive and unsustainable use of land. The development of the organic product market could be one of the important tools to keep land in production longer. However, this type of farming requires a well-functioning institutional environment and support. Some potential in biomass production could be covered as the government plans to increase consumption of this type of energy.

Georgia has the lowest yields for almost all agricultural commodities. The situation could be changed with significant investments in human resources and technological development of the sector. The increase in yields and the enlargement of planted area may be treated as a potential for growth. Grapes have 
the highest potential for development. This product is important for national wine industry, which has good export potential. Apples, hazelnuts and apricots were mentioned by experts as products with growth and export potential. Some progress in the area of organic production was made and further development could be an attractive niche. Increase in biomass production has low potential as this area is not supported by the government.

Yields in Kazakhstan are significantly lower than in countries with a similar agroclimatic conditions. The potential growth could be achieved investing in machinery, plant protection and fertilizers, irrigation systems. Kazakhstan is a leading country in wheat and wheat flour export. This specialization still has growth capacities as yields are very low. Linseed, rapeseed, soya beans and grain maize have export growth potential. Kazakhstan also has export potential for beef and sheep meat. The organic market is on the initial stage of development and has no significant demand on the domestic market. Though the potential of production development is high, the current institutional environment will not encourage remarkable changes in this area. The development of biomass sector in the country is also questionable.

Yields in Armenia still have a potential for development. Absence of irrigation, poor farmers' skills, old machinery and farm plots' fragmentation are the main factors, which influence economic results. Armenia has a good position in the markets of tomatoes, cucumbers, peaches, apricots and grapes. Berries sector is growing and experts mark its potential in the organic farming niche. The country made a notable progress in the development of organic production. Certification system allows labelling and selling products as organic even on foreign markets. Fish and crustaceans production is competitive due to low production costs. Armenian tobacco industry lacks local tobacco, which is cheaper than imported one. Wine and brandy production has growing potential; however, this sector is vulnerable as the high share of its production is exported to Russia.

Productivity and yields in Azerbaijan are lower in all sectors of agriculture. Crop rotation, shift to modern technologies and enlargement of cultivated areas are among the most important factors to increase potential of the agricultural and food sector. The highest potential for growth was noted by: fresh fruit (apples, pomegranates, citrus, etc.), tubers (potatoes), vegetables (cucumbers, tomatoes, cabbages, gherkins, etc.) and animal products (canned meat, eggs, wool, leather, etc.). The government of Azerbaijan plans to increase yields and arable areas of maize, sugar beet, and industrial crops. The potential growth of vegetable, fruit and livestock sector will be achieved by increasing productivity. Azerbaijan does not cover the local demand for meat, milk and fish. That is why the livestock sector provides a good potential for growth. Some progress on the development of the organic market is achieved; however, the well-functioning institutional environment would make this niche more attractive. The rapid development of biomass production in energy-independent country is unlikely. 


\section{References}

Akhramovich, V., Chubrik, A., Shymanovich, G. (2015). AGRICISTRADE country report: Belarus. Retrieved from: http://www.agricistrade.eu/document-library (access date: 30.03.2017).

Arakelyan, M. (2013). CIS frontier countries economic and political prospects. Frankfurt am Main: Deutsche Bank Research. p. 16.

Bluashvili,A., Sukhanskaya, N. (2015). AGRICISTRADE country report: Georgia. Retrieved from: http://www.agricistrade.eu/document-library (access date: 30.03.2017).

Bruinsma, J. (2009). The resource outlook to 2050: By how much do land, water and crop yields need to increase by 2050? Paper presented at the FAO expert meeting on "How to feed the world in 2050". Rome: FAO.

Buchenrieder, G., Hanf, J.H., Pieniadz, A. (2009). 20 years of transition in the agri-food sector. German Journal of Agricultural Economics, no. 58(7), pp. 285-293.

Csaki, C., Forgacs, C. (2008). Agricultural Economics and Transition: What was expected, what we observed, the lessons learned. Proceedings of Joint IAAE-EAAE Seminar. Halle, Germany: IAMO.

Erjavec, E., Volk, T., Rac, I., Kožar, M., Pintar, M., Rednak, M. (2017). Agricultural support in selected Eastern European and Eurasian countries. Post-Communist Economies, 29:2, pp. 216-231, DOI: 10.1080/14631377.2016.1267968.

FAO (2012). The State of Food and Agriculture: Investing in Agriculture for a Better Future. Rome: FAO. Retrieved from: http://www.fao.org/docrep/017/i3028e/i3028e.pdf (access date: 30.03 .2017$)$.

Foresight (2011). The Future of Food and Farming. Final Project Report. London: The Government Office for Science.

Khalilov,H., Shalbuzov, N., Huseyn, R. (2015). AGRICISTRADE country report: Azerbaijan . Retrieved from: http://www.agricistrade.eu/document-library (access date: 30.03 .2017 ).

Lerman, Z. (2009). Land reform, farm structure, and agricultural performance in CIS countries. China economic review 20(2), pp. 316-326.

Lerman, Z., Csaki, C., Feder, G. (2004). Agriculture in Transition: Land Policies and Evolving Farm Structures in Post-Soviet Countries. Landham, MD: Lexington Books.

Liefert, W.M., Liefert, O. (2012). Russian Agriculture during Transition: Performance, Global Impact, and Outlook. Applied Economic Perspectives and Policy (2012), vol. 34, no. 1, pp. 37-75.

Moroz, V., Stratan, A., Ignat, A., Lucasenco, E. (2015). AGRICISTRADE country report: Moldova. Retrieved from: http://www.agricistrade.eu/document-library (access date: 30.03.2017).

Nivievskyi, O., Stepaniuk, O., Movchan, V., Ryzhenkov, M., Ogarenko, Y. (2015). AGRICISTRADE country report: Ukraine. Retrieved from: http://www.agricistrade.eu/ document-library (access date: 30.03.2017).

Rylko, D., Khotko, D., Abuzarova, S., Yunosheva, N., Glazunova, I. (2015). AGRICISTRADE country report: Russia. Retrieved from: http://www.agricistrade.eu/document-library (access date: 30.03 .2017 ). 
Swinnen, J.F., van Herck, K., Vranken, L. (2010). Shifting Patterns of Agricultural Production and Productivity in the Former Soviet Union and Central and Eastern Europe. In: J.M.Alston, B.A. Babcock, P.G. Pardey (ed.), The Shifting Patterns of Agricultural Production and Productivity Worldwide, pp. 279-313. Ames, Iowa: The Midwest Agribusiness Trade Research and Information Center, Iowa State University.

Swinnen, J.F.M., Rozelle, S. (2006). From Marx and Mao to the Market: The Economics and Politics of Agricultural Transition. Oxford: Oxford University Press.

Syzdykov, R., Aitmambet, K., Dautov A. (2015). AGRICISTRADE country report: Kazakhstan. Retrieved from: http://www.agricistrade.eu/document-library (access date: 30.03.2017).

Urutyan, V., Yeritsyan, A., Mnatsakanyan, H. (2015). AGRICISTRADE country report: Armenia. Retrieved from: http://www.agricistrade.eu/document-library (access date: 30.03.2017).

von Cramon-Taubadel, S., Nivyevskiy, O. (2012). Twenty Years of Research on Transition in Agricultural Economics Journals. European Review of Agricultural Economics, no. 39(2), pp. 335-359. 
JOLANTA DROŽDZ

NELE் JURKE்NAITE்

Litewski Instytut Ekonomiki Rolnictwa

Wilno

\title{
POTENCJAŁ SEKTORA ROLNO-SPOŻYWCZEGO W WYBRANYCH KRAJACH WSPÓLNOTY NIEPODLEGŁYCH PAŃSTW
}

\begin{abstract}
Abstrakt
Od początku lat dziewięćdziesiatych dwudziestego wieku w niektórych krajach WNP' (Armenia, Azerbejdżan, Białoruś, Gruzja, Kazachstan, Motdawia, Rosja i Ukraina) rozpoczat sie proces transformacji od gospodarki centralnie planowanej do gospodarki rynkowej. Niektóre z nich maja znacznych rozmiarów sektor rolny. Kraje takie jak Rosja lub Ukraina, odgrywaja ważna role na światowych rynkach. Ten artykut ma na celu pokazanie niewykorzystanego potencjału sektora rolnego tych krajów. W szczególności dotyczy to lepszego zrozumienia problemów związanych $z$ działalnościa rolnicza $w$ wybranych krajach WNP. Artykut zawiera wyniki krajowych sprawozdań, przekrojowych analiz SWOT dotyczacych działalności i potencjału rozwojowego sektora rolno-spożywczego, które uzupełniono o oceny ekspertów.
\end{abstract}

Słowa kluczowe: rolnictwo, rozwój sektora spożywczego, kraje WNP, transformacja.

\footnotetext{
${ }^{1}$ Wspólnota Niepodległych Państw (WNP) powstała w grudniu 1991 r. Obecnie tworzą ją: Azerbejdżan, Armenia, Białoruś, Kazachstan, Kirgistan, Mołdawia, Rosja, Tadżykistan, Turkmenistan i Uzbekistan. Gruzja jest byłym państwem członkowskim, zaś Ukraina - państwem stowarzyszonym. Niniejsza analiza obejmuje: Azerbejdżan, Armenię, Białoruś, Gruzję, Kazachstan, Mołdawię, Rosję i Ukrainę.
}

Accepted for print: 08.09.2017.

Unless stated otherwise all the materials on the website are available under the Creative Commons Attribution 3.0 Poland license. Some rights reserved to the Institute of Agricultural and Food Economics - National Research Institute.

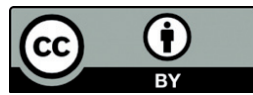

